\title{
Susceptibility of Atlantic cod Gadus morhua juveniles to different routes of experimental challenge with infectious pancreatic necrosis virus (IPNV)
}

\author{
Ingvill Jensen*, Marit Seppola, Kari Steiro, Elin Sandaker, Saskia Mennen, \\ Ann-Inger Sommer
}

Nofima Marin, Box 6122, 9291 Tromsø, Norway

\begin{abstract}
Atlantic cod Gadus morhua L. juveniles weighing $40 \mathrm{~g}$ were challenged with infectious pancreatic necrosis virus (IPNV) by intraperitoneal (i.p.) or intramuscular (i.m.) injection or by bath. The amount of infectious virus was determined over $6 \mathrm{wk}$ in head kidney, heart and pylorus tissues. No mortality or clinical signs were observed in either of the challenged groups. However, 6 wk after challenge virus was still present in the fish, which shows that IPNV can persist asymptomatically in cod. I.p. and i.m. injections were the most efficient routes of challenge giving the highest virus recovery. The prevalence of individuals with a viral titre $\geq 500$ infectious units $\mathrm{g}^{-1}$ tissue was lower in the group of fish challenged by bath; thus bath was a less efficient route of challenge than injection. Our data also show that pylorus and head kidney are target organs for IPNV in cod, and levels of virus recovery were not considerably different between these 2 organs. Challenged by injection, the cod heart is also a target organ for IPNV. Compared to head kidney and pylorus, the heart seems to have a minor role in virus multiplication. Virus was also recovered from cohabiting fish, demonstrating that covertly infected cod may represent a reservoir of infectious IPNV for surrounding fish populations. Expression analysis of selected cod immune genes showed that i.p. injection of IPNV induced gene expression of ISG15 and LGP2, markers for the innate antiviral defence, while expression of markers for the inflammatory response (interleukins IL-1 $\beta$, IL-8, IL-10) was not significantly increased.
\end{abstract}

KEY WORDS: Infectious pancreatic necrosis virus - IPNV - Atlantic cod · Gadus morhua L. Intraperitoneal challenge $\cdot$ Intramuscular challenge $\cdot$ Bath challenge $\cdot$ Cohabitants $\cdot$ Immune genes

Resale or republication not permitted without written consent of the publisher

\section{INTRODUCTION}

The interest in aquaculture of Atlantic cod Gadus morhua L. has increased during recent years due to the reduced supply from wild fisheries, but also partially owing to an elevated market price for cod (Brown et al. 2003, Bolle et al. 2004). Large commercial efforts are currently taking place in Norway, Scotland, Newfoundland (Canada) and New Hampshire (USA) to develop cod aquaculture (Brown et al. 2003, Bolle et al. 2004). Increased susceptibility to infections and horizontal transmission of pathogens are promoted in fish subjected to intensive rearing conditions (reviewed by Wedemeyer 1997). Knowledge of the immune system and which pathogens represent a threat to cod farming is thus of major importance.

Infectious pancreatic necrosis virus (IPNV), the causative agent of infectious pancreatic necrosis (IPN), is widespread in the aquatic environment (Melby et al. 1991, Saint-Jean et al. 2003) and causes disease outbreaks in several fish species such as Atlantic salmon Salmo salar and Atlantic halibut Hippoglossus hippoglossus (Mortensen et al. 1990, Biering et al. 1994, Roberts \& Pearson 2005). IPNV can establish a persistent infection, and salmonids surviving a disease outbreak often become life-long carriers of the virus. Persistently infected fish produce and shed low amounts of virus and may represent a reservoir of infectious 
IPNV for surrounding fish populations (Saint-Jean et al. 2003).

The present knowledge of IPNV infection and disease in cod is limited. Only one disease outbreak caused by IPNV has been reported, which occurred in Denmark and the Faroe Islands (Lorenzen et al. 1995). IPNV has been isolated from wild adult cod with no obvious clinical signs of disease (Skall et al. 2000, Martin-Armas et al. 2007), indicating that the virus is capable of establishing an asymptomatic carrier state in cod. This was confirmed in an experimental challenge of juvenile cod causing no mortality, while IPNV persisted in cod head kidney leucocytes for several months (Garcia et al. 2006).

The teleost innate immune system represents the first line of defence against viral infections, where interferons (IFNs) and IFN-stimulated genes (ISGs) play an essential role (Robertsen 2006). ISG15 and genes involved in the inflammatory response (interleukins IL-1 $\beta$, IL-8 and IL-10) have previously been shown to increase their expression in cod in response to injection with polyinosinic polycytidylic acid (poly I:C), a dsRNA viral mimic (Seppola et al. 2007, 2008), suggesting a role in antiviral defence. Another immune gene called LGP2 has not previously been described in fish. In mammals, LGP2 possesses strong binding affinity for dsRNA and functions as a negative regulator for the induction of IFNs (Akira et al. 2006). In this work, a cod LGP 2 cDNA sequence was obtained (CODGEN at the Institute of Marine Research, Norway) and, along with the other mentioned immune genes, was used as a marker for activation of cod innate immunity. Expression analysis of immune genes during the course of a virus infection can contribute to understanding their role in antiviral defence.

The aim of the present work was to study whether IPNV established an infection in juvenile cod by 4 different routes of challenge: intraperitoneal (i.p.) injection, intramuscular (i.m.) injection, bath challenge and cohabitant challenge. Over a 6 wk period, the amount of infectious IPNV was detected in different organs to assess whether the infection persisted or was cleared by the fish. Furthermore, expression of the immune genes IL-1 $\beta$, IL-8, IL-10, ISG15 and LGP2 was studied in cod challenged with IPNV by i.p. injection.

\section{MATERIALS AND METHODS}

Fish and rearing conditions. Non-vaccinated juvenile Atlantic cod Gadus morhua L. were obtained from a local hatchery. The fish were transferred to the Fish Health Unit at the Tromsø Aquaculture Research Station and kept in seawater in $200 \mathrm{l}$ flow-through tanks.
They were gradually acclimatised to a water temperature of $12^{\circ} \mathrm{C}$ before challenge. The fish were fed according to appetite (Dana Feed A/S) and kept in continuous daylight. The reported experiment was conducted in accordance with the European Convention for the Protection of Vertebrate Animals used for Experimental and other Scientific Purposes of 18 March 1986.

Virus for challenge. An IPNV strain (H-IPNV/ GW98), originally isolated during an epidemic among farmed Atlantic halibut in the northern part of Norway, was re-isolated from experimentally infected cod juveniles in a previous challenge experiment (A.-I. Sommer et al. unpubl.). A second cell culture passage of this virus strain, H-IPNV/GW98/C03, was used in the present experiment.

The chinook salmon embryo cell line CHSE-214 (Lannan et al. 1984) was used for IPNV isolation and propagation. The cells were cultured in Eagle's minimum essential medium (EMEM) supplemented with antibiotics, $1 \%$ non essential amino acids, $200 \mathrm{mM}$ L-glutamine and $8 \%$ foetal calf serum (FCS, PAA Laboratories). For virus propagation, the FCS content was reduced to $2 \%$. CHSE-214 cells were incubated in 5\% $\mathrm{CO}_{2}$ at $20^{\circ} \mathrm{C}$. The IPNV isolate was added at a multiplicity of infection of 0.1 and incubated until complete cytopathic effect (CPE) was evident, usually after $7 \mathrm{~d}$. Cell culture medium and the remaining cells were recovered and centrifuged at $920 \times g$ for $15 \mathrm{~min}$. To recover virus from the cell pellet, it was frozen/thawed, sonicated and centrifuged at $920 \times g$ for $10 \mathrm{~min}$. The resulting supernatant was pooled with the clarified cell culture medium and stored at $-80^{\circ} \mathrm{C}$ until challenge. Aliquots were used to determine TCID $_{50}$ by end-point dilution (Reed \& Muench 1938) with 8 replicates on CHSE-214 cells.

Challenge. Mean $( \pm$ SD) weight of the fish on the day of challenge was $39.4 \pm 11.6 \mathrm{~g}(\mathrm{n}=17)$. No feed was given $24 \mathrm{~h}$ prior to challenge. Prior to injections, the fish were anaesthetised by immersion in Metacainum (50 $\mathrm{mg} \mathrm{l}^{-1}$, Norsk Medisinaldepot). The fish were marked on the operculum with visible implant fluorescent elastomer (Northwest Marine Technology).

Fish were injected i.p. $(\mathrm{n}=100)$ and i.m. $(\mathrm{n}=100)$ with $0.1 \mathrm{ml}$ virus inoculum $\left(6.3 \times 10^{5} \mathrm{TCID}_{50} \mathrm{fish}^{-1}\right)$, prepared as described above. These 2 groups of fish were kept in the same tank. In a separate tank, 100 fish were bath-challenged over a period of $3.5 \mathrm{~h}$ in 501 oxygenated sea water containing $1 \times 10^{5} \mathrm{TCID}_{50} \mathrm{ml}^{-1}$ of the virus isolate. Three days after challenge, 10 cohabitants were added to each of the 2 tanks with challenged fish. The control group consisted of 35 fish injected i.p. and 35 fish injected i.m. with $0.1 \mathrm{ml}$ EMEM with $2 \%$ FCS, and was kept in a separate tank in a separate room. The fish that were not sampled, as des- 
cribed below, were maintained for observation for clinical signs and mortality. The experiment was terminated $42 \mathrm{~d}$ after challenge.

IPNV carrier testing. Before challenge, heart and head kidney of 10 fish were checked for the presence of IPNV by carrier tests as described previously with minor modifications (Johansen \& Sommer 2001). Briefly, organ homogenates were seeded on CHSE-214 cells in $80 \mathrm{~cm}^{2}$ cell culture flasks. Samples from 2 individuals were pooled and seeded in each flask. Two blind passages were performed. The lower detection limit per pool of 2 individuals was 5 infectious units (i.u.) $\mathrm{g}^{-1}$ tissue.

Sampling and virus titration. Seven, 14, 21 and $42 \mathrm{~d}$ after challenge, 10 fish from each challenged group (i.p., i.m., bath) were killed by an overdose of the anaesthetic benzocain, and heart, head kidney and pylorus were aseptically removed. Each organ was divided in 2 parts; 1 part was frozen at $-80^{\circ} \mathrm{C}$ and stored for IPNV detection and titration, while the other part was rapidly submerged in RNAlater and stored at $-20^{\circ} \mathrm{C}$ for gene expression analysis. From the control group, the same organs were sampled from 10 fish $7 \mathrm{~d}$ after challenge and from 20 fish $42 \mathrm{~d}$ after challenge.

Each organ was thawed and homogenised individually in EMEM with $2 \%$ FCS by passing it through a $100 \mu \mathrm{m}$ cell strainer (BD Biosciences) and further centrifuged at $12500 \times g$ for $10 \mathrm{~min}$. Homogenates for 1 type of organ from 5 individuals were pooled and inoculated onto CHSE-214 cells in $80 \mathrm{~cm}^{2}$ cell culture flasks at a concentration of $0.5 \%(\mathrm{w} / \mathrm{v})$. Whether CPE due to IPNV was evident was registered after $7 \mathrm{~d}$. One blind passage was done with all pools. The lower detection limit per pool of 5 individuals was 10 i.u. $\mathrm{g}^{-1}$ tissue.

Individual viral titres for each organ were obtained by inoculation of 10 -fold dilutions of the homogenised organs in 2 replicates on CHSE-214 cells. End-point titres were calculated. The lower detection limit for individual titres was 500 i.u. $\mathrm{g}^{-1}$ tissue. For calculation of means of viral titres, individuals negative in individual titration were given an arbitrary value of 1 , thus taking into consideration the total number of individuals analysed. For some of the samples where CPE was registered, the presence of IPNV was verified by neutralisa- tion using IPNV-specific polyclonal antibodies produced in rabbit.

RNA isolation, RT-PCR and sequencing of IPNV viral capsid protein VP2. Cell culture medium from CPE-positive CHSE-214 cells inoculated with pooled organ homogenates, prepared as described above, were used as a basis for RNA isolation and further VP2 sequencing. In order to initially fracture viruses before RNA isolation, $250 \mu \mathrm{l}$ cell culture medium, $275 \mu \mathrm{l}$ lysis buffer (1\% SDS, $0.15 \mathrm{M} \mathrm{NaCl}, 1.25$ mM EDTA, $0.1 \mathrm{M}$ Tris- $\mathrm{HCl}, \mathrm{pH} 7.6$ ) and $0.5 \mathrm{mg}$ Proteinase $\mathrm{K}$ (Applied Biosystems) were mixed and incubated at $37^{\circ} \mathrm{C}$ for 90 min. From this solution, RNA was isolated using Trizol LS reagent (Invitrogen Life Technologies), and dissolved in Nuclease-free water (Promega). Quality and quantity of the RNA were measured using the NanoDrop ND-100 spectrophotometer (NanoDrop Technologies). Synthesis of cDNA was performed using the recommended protocol supplied with Superscript III RNase H-Reverse transcriptase (Invitrogen Life Technologies).

A selected region (614 bp) of the gene encoding VP2 of IPNV was amplified by PCR using the primers LVP2F and LVP2R (Eurogentec; Table 1). The PCR conditions were $2 \mu \mathrm{l}$ CDNA, $0.6 \mu \mathrm{M}$ of each primer, $0.2 \mathrm{mM}$ dNTP, $1 \times$ enzyme buffer (Promega) and $1 \mathrm{U}$ Pfu polymerase (Promega) in a $50 \mu$ reaction volume. Thermocycling conditions were as follows: initial denaturation at $95^{\circ} \mathrm{C}$ for $2 \mathrm{~min}$, followed by 35 cycles at $95^{\circ} \mathrm{C}$ for $5 \mathrm{~s}, 62^{\circ} \mathrm{C}$ for $15 \mathrm{~s}, 72^{\circ} \mathrm{C}$ for $30 \mathrm{~s}$ and final extension at $72^{\circ} \mathrm{C}$ for $7 \mathrm{~min}$. PCR products were treated with ExoSAP IT (USB) for digestion of primers and nucleotides. The PCR products were sequenced using the ABI Big Dye Terminator Cycle Sequencing Kit version

Table 1. Primer sequences and their designated application. eF: elongation factor

\begin{tabular}{|c|c|c|}
\hline Primer name & Sequence $\left(5^{\prime}-3^{\prime}\right)$ & Application \\
\hline LVP2F & CGAACCCCCAGGACAAAGT & Sequencing IPNV VP2 \\
\hline LVP2R & GTGATTGGTCTGAGCACGC & Sequencing IPNV VP2 \\
\hline IPNV-NS-1828F & AGGTCCTATCCCACTTCGCAAA & Real-time PCR \\
\hline IPNV-NS-1900R & TCTCCCTCGAAGGGTATGTCCT & Real-time PCR \\
\hline LGP2-435F & GCTTCTCGGACATCACTCTGCT & Real-time PCR \\
\hline LGP2-508R & TCTGGTTGTAAACTCССТCTTTGTG & Real-time PCR \\
\hline ISG15-32F & TAACCAGACAGCAGTTGGTCATG & Real-time PCR \\
\hline ISG15-108R & TGGAGCCACGGTAAGAGGG & Real-time PCR \\
\hline IL1b-658F & GGAGAACACGGACGACCTGA & Real-time PCR \\
\hline IL1b-708R & CGCACCATGTCACTGTCCTT & Real-time PCR \\
\hline IL8-446F & GGTTTGTTCAATGATGGGCTGTT & Real-time PCR \\
\hline IL8-516R & GACCTTGCСТCCTCATGGTAATACT & Real-time PCR \\
\hline IL10-618F & CCTATAAAGCCATCGGCGAGTTA & Real-time PCR \\
\hline IL10-693R & TGAAGTCGTCGTTTTGAACCAAG & Real-time PCR \\
\hline $18 \mathrm{SF}$ & GAGCCTAGAAATGGCTACCACATC & Real-time PCR \\
\hline 18SR & CACGTGTCGTGAATGGGTAATT & Real-time PCR \\
\hline $\mathrm{eF} 1_{\mathrm{a} 1}-148 \mathrm{~F}$ & ATGTGAGCGGTGTGGCAATC & Real-time PCR \\
\hline $\mathrm{eF} 1_{\mathrm{a} 1}-220 \mathrm{R}$ & TCATCATCCTGAACCACCCTG & Real-time PCR \\
\hline
\end{tabular}


3.1 (Applied Biosystems). Sequences were analysed by Lasergene SeqMan II software (DNASTAR).

RNA isolation from organs and real-time PCR. RNA was isolated from head kidneys from 10 non-injected, unchallenged fish sampled before the start of the experiment, from injected control fish (10 fish sampled 7 and $42 \mathrm{~d}$ after challenge, respectively) and from i.p. IPNV-challenged fish (10 fish sampled 7, 14, 21 and $42 \mathrm{~d}$ after challenge, respectively). The E.Z.N.A. Total RNA kit (OMEGA BIO-TEK) was used for RNA isolation using the recommended on-column DNase treatment. RNA was subsequently subjected to a second insolution DNase treatment (Promega) according to the manufacturer's instructions. The synthesis of cDNA was performed using Taqman RT Reagents (Applied Biosystems) mainly according to the recommended protocol (Seppola et al. 2007). Quantitative real-time PCR was performed for the target genes IL-1 $\beta$, IL-8, IL10, ISG15 and LGP2 (GenBank accession number EU371924) using the ICycler iQ real-time PCR detection system (Bio-Rad) and Core kit for SYBR (Eurogentec), as described previously (Seppola et al. 2007, 2008). Real-time primers for target genes and endogenous controls (18S and eF1 $\alpha$ ) are listed in Table 1.

A real-time PCR assay was designed to amplify a section of IPNV segment A for detection of the relative amount of IPNV RNA (primers are listed in Table 1). A positive virus control was included in all runs to equalise the detected amount of virus, and the lowest detection limit of virus was set to threshold cycle $\left(C_{\mathrm{T}}\right)$ value 35 . The PCR efficiencies were determined by analysis of 2-fold or 5-fold serial dilutions of cDNA, and efficiencies were close to $100 \%$ allowing use of the $2^{-\Delta \Delta C_{\mathrm{T}}}$ method for calculation of relative gene expression (Livak \& Schmittgen 2001). The mean quantity \pm SEM of the relative gene expression was calculated from values obtained from 10 fish. Statistical analyses between groups were made with an unpaired 2-tailed Student's $t$-test, and $\mathrm{p}<0.05$ was considered significant.

\section{RESULTS}

\section{Screening for IPNV carriers in control fish}

Before initiation of the experiment, heart and head kidney of 10 fish were checked for the presence of IPNV by carrier tests in pools of 2 individuals. The lower detection limit per pool of 2 individuals was 5 i.u. $\mathrm{g}^{-1}$ tissue. No IPNV-positive pools were found. During the experiment, fish were sampled from the control group 7 and $42 \mathrm{~d}$ after challenge. Head kidney, heart and pylorus were checked for IPNV in 16 pools of 5 individuals. Two pools from head kidney and 1 pool from heart at the sampling $42 \mathrm{~d}$ after challenge were positive for IPNV, although all were negative by individual titrations on CHSE-214 cells. The lower detection limit per pool of 5 individuals was 10 i.u. $\mathrm{g}^{-1}$ tissue, and for individual titrations the detection limit was 500 i.u. $\mathrm{g}^{-1}$ tissue. Detection of IPNV by real-time PCR analysis confirmed that no virus was present in the individuals sampled before challenge. In the control fish sampled $42 \mathrm{~d}$ after challenge, viral RNA was present in head kidney samples from 8 of 10 individuals, most likely representing IPNV carriers.

\section{Detection of infectious IPNV in challenged fish}

We studied the susceptibility of Atlantic cod juveniles $(40 \mathrm{~g})$ to infection with IPNV and how 3 routes of challenge (i.p. or i.m. injection or bath) affected the outcome of infection. Head kidney, heart and pylorus sampled 7, 14, 21 and $42 \mathrm{~d}$ after challenge were analysed for the presence of infectious virus in organhomogenates pooled from 5 individuals (lower detection limit per pool of 5 individuals of 10 i.u. $\mathrm{g}^{-1}$ tissue) and by individual virus titrations (lower detection limit of 500 i.u. $\mathrm{g}^{-1}$ tissue). During the experimental period no mortality or clinical signs of disease were observed in the control group, challenged groups or cohabitants.

Infectious virus was recovered from internal organs of fish in all 3 challenged groups; however, the prevalence of individuals with viral titres $\geq 500$ i.u. $\mathrm{g}^{-1}$ tissue and levels of the viral titres differed between groups (Fig. 1). In the i.p. injected group (Fig. 1a), highest viral titres were recorded in pylorus with mean titres ranging from $3.0 \times 10^{4}$ to $6.4 \times 10^{5}$ i.u. $\mathrm{g}^{-1}$ tissue 42 and $7 \mathrm{~d}$ post challenge, respectively. Intermediate viral titres were found in head kidney with mean titres ranging from $2.1 \times 10^{3}$ to $2.5 \times 10^{4}$ i.u. $\mathrm{g}^{-1}$ tissue 42 and $7 \mathrm{~d}$ post challenge, respectively. Lowest viral titres were found in heart, where the prevalence of individuals with viral titres $\geq 500$ i.u. $\mathrm{g}^{-1}$ tissue was only $27 \%$ (8/30). Seven of these were individuals sampled $21 \mathrm{~d}$ after challenge showing a mean viral titre of $9.0 \times 10^{2} \mathrm{i} . \mathrm{u}^{-1} \mathrm{~g}^{-1}$ heart tissue. However, virus was also present in heart samples at the other sampling points, but at lower levels only detectable in pools.

In the i.m. injected fish (Fig. 1b), similar results as for the i.p. group were obtained. However, the prevalence of individuals with viral titres $\geq 500$ i.u. $\mathrm{g}^{-1}$ tissue and viral titres were slightly lower in this group compared to the i.p. group. This was most pronounced in samples from pylorus, where mean viral titres ranged from $2.6 \times$ $10^{3}$ to $1.0 \times 10^{4}$ i.u. $\mathrm{g}^{-1}$ tissue 7 and $14 \mathrm{~d}$ after challenge, respectively. The prevalence of individuals with viral titres $\geq 500$ i.u. $\mathrm{g}^{-1}$ tissue was $67 \%$ for the 39 pylorus samples tested in this group, compared to $98 \%$ of the 40 

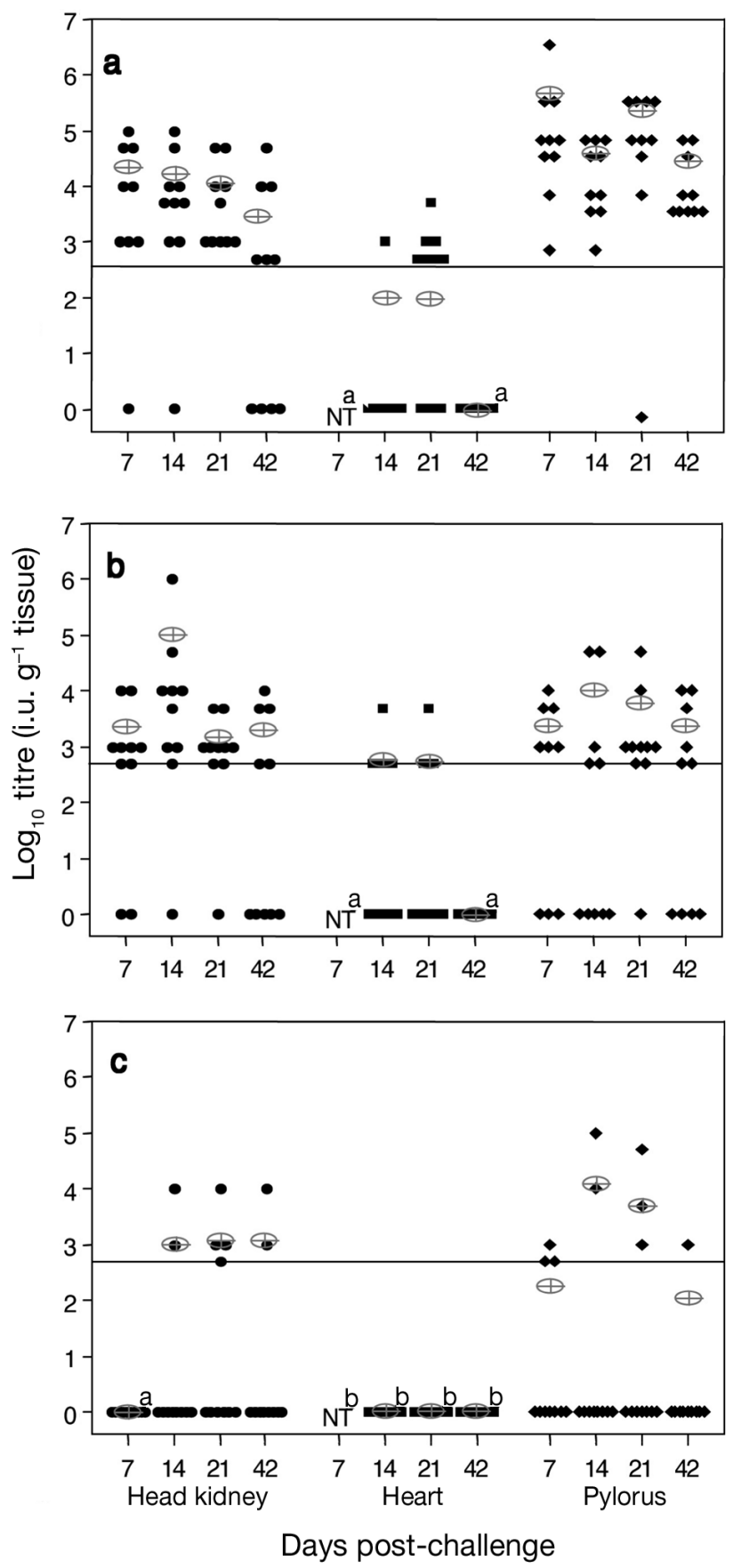

Fig. 1. Detection of infectious virus in organs from Atlantic cod Gadus morhua challenged with an IPNV isolate from Atlantic halibut by (a) i.p. injection, (b) i.m. injection or (c) bath. Organs were sampled from 10 fish per group, and homogenates were tested for infectious virus in 2 pools of 5 individuals and by individual titration on CHSE-214 cells. Horizontal line shows $\log _{10}$ of the detection limit of the titration method at 500 infectious units (i.u.) $\mathrm{g}^{-1}$ tissue. Individuals negative in individual titration were given an arbitrary value of 1 , which is below the detection level of the method. Solid symbols: individual titres; $\oplus$ : mean viral titres. Superscript a (b) indicates samples that were positive (negative) in pools, but negative (positive) in individual titration. NT: not tested in individual titration pylorus samples tested in the i.p. group. In head kidney, mean titres ranged from $1.6 \times 10^{3}$ to $1.1 \times 10^{5}$ i.u. $\mathrm{g}^{-1}$ tissue 21 and $14 \mathrm{~d}$ after challenge, respectively. The prevalence of individuals with viral titres $\geq 500$ i.u. $\mathrm{g}^{-1}$ tissue was $78 \%$ for the 40 head kidney samples tested in the i.m. group, and $87 \%$ for the 39 head kidneys tested in the i.p. group. Also in the i.m. group, lowest viral titres were obtained from heart samples, and the prevalence of individuals with viral titres $\geq 500$ i.u. $\mathrm{g}^{-1}$ tissue was only $23 \%$ for the 30 samples analysed.

A lower viral load was present in the fish challenged by bath (Fig. 1c) than in the injected fish. In contrast to the results from the other challenged groups, 7 of the 8 pooled organ homogenates from heart and 1 of 8 pooled organ homogenates from head kidney were IPNV negative. This was also reflected in low viral titres, and the prevalence of individuals with viral titres $\geq 500$ i.u. $\mathrm{g}^{-1}$ tissue was $20 \%$ for the 40 head kidney samples (mean range: 1 to $1.3 \times 10^{3}$ i.u. $\mathrm{g}^{-1}$ tissue 7 and $21 \mathrm{~d}$ after challenge), and $23 \%$ for the 40 pylorus samples (mean range: $1.1 \times 10^{2}$ to $1.2 \times 10^{4} \mathrm{i} . \mathrm{u}^{-1} \mathrm{~g}^{-1}$ tissue 42 and $14 \mathrm{~d}$ after challenge). No heart samples had viral titres $\geq 500$ i.u. $\mathrm{g}^{-1}$ tissue after bath challenge.

During the experiment, viral titres within each of the studied organs were relatively stable after all 3 routes of challenge. The prevalence of individuals with viral titres $\geq 500$ i.u. $\mathrm{g}^{-1}$ tissue was at least $50 \% 42 \mathrm{~d}$ after i.p. or i.m. challenge. In the bath-challenged group, the prevalence of individuals with viral titres $\geq 500$ i.u. $\mathrm{g}^{-1}$ tissue was only $20 \%$ after 42 d.

\section{Detection of infectious virus in cohabiting fish}

To determine whether IPNV was transmitted to healthy fish, cohabiting fish were analysed for the presence of IPNV $42 \mathrm{~d}$ after challenge (Table 2). For both groups of cohabitants (i.p./i.m. and bath), virus was detected in all organs analysed (head kidney, heart and pylorus) in pooled organ homogenates. Indi-

Table 2. Gadus morhua. Detection of IPNV in organ samples from cohabitants $42 \mathrm{~d}$ after challenge. + and - indicate whether CHSE-214 cells infected with pooled organ homogenates from 5 individual fish were CPE positive or negative. Two pools (total of 10 individuals) were analysed for each organ and experimental group. Numbers in parentheses indicate the prevalence of individuals with viral titres $\geq 500$ infectious units $\mathrm{g}^{-1}$ tissue

\begin{tabular}{|lcc|}
\hline Organ & I.p. and i.m. challenge & Bath challenge \\
\hline Head kidney & $+/+(10 \%)$ & $+/-(10 \%)$ \\
Heart & $+/+$ & $+/-$ \\
Pylorus & $+/+(30 \%)$ & $+/-(11 \%)$ \\
\hline
\end{tabular}


vidual titres were obtained from a few cohabitants and ranged from $5 \times 10^{2}$ to $5 \times 10^{4}$ i.u. $\mathrm{g}^{-1}$ tissue (not shown).

\section{Sequence analysis of IPNV VP2}

Sequencing of a variable region of the gene encoding the viral capsid protein VP2 showed that the VP2 sequence recovered from injected fish and cohabiting fish was identical to the VP2 sequence of the challenge strain $\left(\mathrm{Pro}^{217}, \mathrm{Thr}^{221}, \mathrm{Tyr}^{226}, \mathrm{Ala}^{247}, \mathrm{Ala}^{251}, \mathrm{Ala}^{278}\right.$ ). However, the VP2 sequence recovered from fish in the control group had 5 nucleotide substitutions compared to the challenge strain, which resulted in a different amino acid composition in 3 of these 5 positions $\left(\mathrm{Thr}^{217}\right.$, $\left.\mathrm{Thr}^{221}, \mathrm{Tyr}^{226}, \mathrm{Thr}^{247}, \mathrm{Ala}^{251}, \mathrm{Val}^{278}\right)$. These results show that the virus detected in the cohabitants was most likely transmitted through the water from the challenged fish, whereas the virus recovered from the control group was different from the challenge strain.

\section{Immune gene expression and detection of IPNV by real-time PCR}

An evaluation of gene expression of the 2 endogenous controls, $18 \mathrm{~S}$ and $\mathrm{eF} 1 \alpha$, was performed with fish challenged by i.p. injection of IPNV and control fish. No significant differences in gene expression $(p>0.05)$ were observed between $18 \mathrm{~S}$ and $\mathrm{eF} 1 \alpha$ in challenged and control fish, and $18 \mathrm{~S}$ was thus used as endogenous control for all real-time PCR analysis. Expression of immune genes was assayed by real-time PCR in head kidneys from cod injected i.p. with IPNV at 7, 14, 21

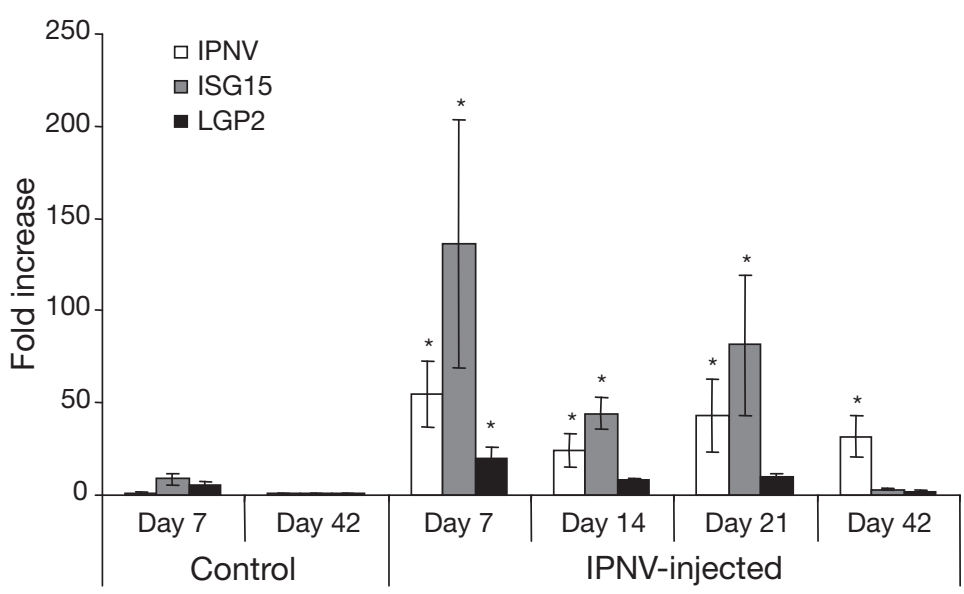

Fig. 2. Gadus morhua. Relative quantification of IPNV NS protein gene and cod immune gene (ISG-15, LGP2) expression by real-time PCR analysis of IPNV-injected fish and control fish. Fish were injected intraperitoneally with IPNV or cell culture medium (control) and gene expression was determined in head kidney. Levels of gene expression were normalised to head kidney sampled from non-injected fish (calibrator). 18S served as endogenous control for real-time PCR quantification. Error bars: SEM $(n=10)$. ${ }^{*}$ Significant differences to the calibrator $(p<0.05)$ and $42 \mathrm{~d}$ post challenge (Fig. 2). ISG15 showed the most marked induction of gene expression on Day 7 (136-fold; $\mathrm{p}=0.05$ ), while the expression was slightly reduced on Day 14 (44-fold; $\mathrm{p}<0.01)$ and Day 21 (81fold; $\mathrm{p}=0.05)$. This elevation in expression had declined to the level observed in control fish at $42 \mathrm{~d}$ post challenge. Similar to ISG15, the expression of LGP2 was elevated on Day 7 (20-fold, $\mathrm{p}<0.01$ ); however, at later sampling points this elevation was diminished. The pro-inflammatory cytokines (IL-1 $\beta$ and IL-8) and the anti-inflammatory cytokine IL-10 showed no significant increase in gene expression. The relative amount of IPNV RNA was also assayed by real-time PCR in the same organ samples as those used for immune gene expression analysis. Real-time PCR confirmed that no virus was present in the individuals tested before challenge, while a high amount of viral RNA was present in head kidney from the IPNVinjected fish. The highest amount of viral RNA was detected by real-time PCR on Day 7 and remained relatively stable throughout the experimental period. This is concurrent with detection of infectious virus by viral titrations.

\section{DISCUSSION}

This study demonstrates the establishment of an IPNV infection in juvenile Atlantic cod after challenge by injection (i.p. and i.m.) or bath. To our knowledge, this is the first time these 3 routes of challenge have been directly compared with IPNV in general. I.p. and i.m. injections were the most efficient routes of challenge, giving the highest virus recovery from internal organs. With the experimental conditions used in the present experiment, it seems that IPNV gains access equally well to the target organs analysed by either of these 2 routes of injection. For the fish challenged by bath, infectious virus was also present in internal organs, but the prevalence of individuals with a viral titre $\geq 500$ i.u. g $^{-1}$ tissue was considerably lower in this group. Thus bath was a less efficient route of challenge than injection, but it better reflects the risk of natural horizontal infection in fish of this size.

No mortality or clinical signs were observed in either of the challenge groups, which shows that the virus can persist in asymptomatically infected cod. Covert infections without clinical signs are commonly established after IPNV challenge of juveniles of other fish species (Bootland et al. 1991, Novoa et al. 1995a, b, Sommer et al. 2004) Recently, this was also demonstrated in cod (Garcia et al. 2006). Small fry are 
generally the most susceptible to IPNV-induced mortality (Novoa et al. 1993, Biering et al. 1994, Sommer et al. 2004), but the viral strain and water temperature also have an influence (Saint-Jean et al. 2003, Santi et al. 2004). The viral strain used in this experiment was originally isolated from IPN diseased halibut fry and has caused high mortality in bath-challenged spotted wolffish fry (Sommer et al. 2004). Further experiments are required, with smaller sizes of fish to establish whether this viral strain is also able to cause mortality in cod.

Our data show that pylorus and head kidney are target organs for IPNV in cod, and levels of virus recovery were not considerably different between these 2 organs. IPNV is frequently isolated from pylorus and head kidney in other species (Saint-Jean et al. 2003). Pylorus contains the pancreatic tissue, which is the main organ affected by acute IPN (Saint-Jean et al. 2003). In head kidney, IPNV has been specifically associated with leucocytes/macrophages in salmonids (Johansen \& Sommer 1995, Munro et al. 2006) and recently also in experimentally infected cod (Garcia et al. 2006). IPNV also established an infection in cod heart, although low viral titres were obtained. The cod heart endocardium is lined with scavenger endothelial cells (SECs) that are very active in uptake and degradation of macromolecular waste (Seternes et al. 2001, 2002). Recently, these cells were shown to be susceptible to IPNV infection in vitro, and it was also demonstrated that in wild adult cod, SECs from heart were covertly infected with IPNV (Martin-Armas et al. 2007). Our study supports these recent data and suggests a role for the cod heart as a target organ after in vivo injection of IPNV. However, compared to head kidney and pylorus, the heart seems to play a minor role in virus multiplication.

The highest individual titres reaching $1 \times 10^{5}$ to $5 \times$ $10^{6}$ i.u. $\mathrm{g}^{-1}$ tissue were observed in head kidney and pylorus during the first $3 \mathrm{wk}$ after injection. When this IPNV strain was used for challenge of smaller juveniles of spotted wolffish, titres of $10^{5}$ to $10^{8} \mathrm{TCID}_{50} \mathrm{~g}^{-1}$ tissue were registered in IPN-diseased fish after 4 wk. The infection was reported to still persist after 4 mo with titres of $10^{3.5} \mathrm{TCID}_{50} \mathrm{~g}^{-1}$ tissue, demonstrating a carrier state of IPNV (Sommer et al. 2004). Whether the present experimental IPNV infection in cod would have developed into a carrier state is not known. However, the infection persisted for $6 \mathrm{wk}$ with only minor mean titre reduction, which supports this assumption.

At the end of the experimental period, some IPNVpositive individuals were found in the control group. We do not know the source of this infection, but the fish could have been IPNV carriers when obtained from the commercial supplier. This is supported by the results from the VP2 sequencing, which showed that this virus was different from the isolate used for challenge. Previ- ous results have shown that wild cod can be IPNV carriers (Martin-Armas et al. 2007), which further supports this suggestion. In Atlantic salmon, quiescent IPNV can be reactivated and cause acute infections, especially upon stressful conditions (Taksdal et al. 1998). However, we find it unlikely that the IPNV carrier virus found in our study contributed to the viral titres obtained from the challenged fish. This is supported by the very low viral titres present in a few fish in the control group (below 500 i.u. $\mathrm{g}^{-1}$ tissue) only detected $42 \mathrm{~d}$ after the start of the experiment. Also, the VP2 sequencing data demonstrated the presence of only 1 viral sequence in the challenged group, confirming no reactivation of the carrier virus. Limited information is available regarding re-challenge of fish carrying IPNV and whether the carrier condition affects the outcome of the infection. IPNV is inhibited by the antiviral effects of the salmonid IFN-system (Jensen \& Robertsen 2002), and one could speculate that the carrier virus induced this system and thus protection against the virus infection in the experimental challenge. If this was the case, we would have expected to see high levels of ISG15 expression in the control fish at $42 \mathrm{~d}$ where carrier virus actually was detected. However, ISG15 expression was very low in control fish, and it seems that the antiviral IFN system of the cod is not induced by the carrier condition. This is supported by studies of Atlantic salmon IPNV carriers, demonstrating no detectable expression of the Mx gene (Lockhart et al. 2004) and no protective effect on a secondary IPNV infection (Johansen \& Sommer 2001).

VP2 sequencing demonstrated that the virus isolated from the cohabitants was identical to the strain used for challenge and that the virus isolated from the control group was different from these 2 isolates. We can thus conclude that virus was transmitted from the challenged fish through the water to the cohabiting fish. The least efficient route of challenge was by bath; nevertheless, these fish transmitted the virus to the surroundings, demonstrating the possible risk of natural horizontal infection from covert IPNV carriers among farmed and wild cod.

Analysing immune gene expression can contribute to understanding which mechanisms determine the outcome of an IPNV infection. ISG15 has recently been shown to possess antiviral activity in mammals (Okumura et al. 2006, Lenschow et al. 2007), while cod ISG15 gene expression is strongly induced by the synthetic double-stranded RNA poly I:C (Seppola et al. 2007). Others have also recently shown ISG15 expression in liver of cod fry up to $21 \mathrm{~d}$ after IPNV injection (Das et al. 2007). LGP2 has not previously been described in fish, but in mammals, LGP2 is a negative regulator of intracellular antiviral signalling (Rothenfusser et al. 2005, Yoneyama et al. 2005). We used cod 
ISG15 and LGP2 as markers for the innate antiviral response. In the present experiment, IPNV injection induced expression of both ISG15 and LGP2 in head kidney during the first weeks post challenge, with ISG15 showing the most marked increase in gene expression. Six weeks post challenge levels had declined to levels observed in control fish. This decline in expression could indicate transfer to a carrier state with a silent IPNV infection that no longer activates immune defence. However, further experiments are required to elucidate the possible antiviral function of these genes in cod and how a covert infection influences immune gene expression.

The cod inflammatory markers IL-1 $\beta$ and IL-8 and the anti-inflammatory IL-10 (Seppola et al. 2008) showed no significant increase in gene expression in response to IPNV infection. In previous in vitro experiments with adherent head kidney cells from cod, IL-1 $\beta$ expression was enhanced 24 and $48 \mathrm{~h}$ after IPNV infection using the same virus isolate as in this in vivo challenge, while IL-8 and IL-10 did not respond to IPNV (Seppola et al. 2008). However, in the present experiment, IL-1 $\beta$ gene expression in vivo might have occurred ahead of the first sampling point $7 \mathrm{~d}$ after challenge. This is implied by results from other fish species where an increase in IL-1 $\beta$ and IL-8 expression have been detected in vivo 1 to $3 \mathrm{~d}$ post infection for several viruses, including IPNV (Purcell et al. 2004, Tafalla et al. 2005, 2006, Overturf \& LaPatra 2006, Poisa-Beiro et al. 2008). On the other hand, it might be possible that cod interleukins are not modulated in response against IPNV, as McBeath et al. (2007) showed no increase of IL-1 $\beta$ after IPNV challenge in Atlantic salmon.

In summary, our study describes the establishment of a persistent IPNV infection in cod juveniles after challenge by i.p. and i.m. injections and by bath. Major differences were seen between challenge by injection or bath, with bath being the least efficient route of challenge giving the lowest virus recovery from internal organs. However, in all 3 groups, IPNV persisted for the experimental period of $42 \mathrm{~d}$. Virus was transmitted both from the injected fish and bath-challenged fish to cohabitants, demonstrating the possibility of covertly infected cod being a reservoir of infectious IPNV for surrounding fish populations. However, other important aspects of this persistent IPNV infection are still not understood in cod, such as the extent of pathological changes and whether reactivation of infection can occur.

Acknowledgements. This project was financially supported by Innovasjon Norge and the Research Council of Norway (project number 158952). K. Julin is acknowledged for providing primers for sequencing VP2 of IPNV, and valuable guidance for interpretation of sequencing data. CODGEN at the
Institute of Marine Research, Norway, is acknowledged for providing the cod LGP2 cDNA sequence.

\section{LITERATURE CITED}

Akira S, Uematsu S, Takeuchi O (2006) Pathogen recognition and innate immunity. Cell 124:783-801

$>$ Biering E, Nilsen F, Rodseth OM, Glette J (1994) Susceptibility of Atlantic halibut Hippoglossus hippoglossus to infectious pancreatic necrosis virus. Dis Aquat Org 20: 183-190

Bolle LJ, Rijnsdorp AD, Van Neer W, Millner RS and others (2004) Growth changes in plaice, cod, haddock and saithe in the North Sea: a comparison of (post-)medieval and present-day growth rates based on otolith measurements. J Sea Res 51: 313-328

Bootland LM, Dobos P, Stevenson RMW (1991) The IPNV carrier state and demonstration of vertical transmission in experimentally infected brook trout. Dis Aquat Org 10: $13-21$

Brown JA, Minkoff G, Puvanendran V (2003) Larviculture of Atlantic cod (Gadus morhua): progress, protocols and problems. Aquaculture 227:357-372

Das BK, Collet B, Snow M, Ellis AE (2007) Expression kinetics of ISG15 and viral major capsid protein (VP2) in Atlantic cod (Gadus morhua L.) fry following infection with infectious pancreatic necrosis virus (IPNV). Fish Shellfish Immunol 23:825-830

> Garcia J, Urquhart K, Ellis AE (2006) Infectious pancreatic necrosis virus establishes an asymptomatic carrier state in kidney leucocytes of juvenile Atlantic cod, Gadus morhua L. J Fish Dis 29:409-413

Jensen I, Robertsen B (2002) Effect of double-stranded RNA and interferon on the antiviral activity of Atlantic salmon cells against infectious salmon anemia virus and infectious pancreatic necrosis virus. Fish Shellfish Immunol 13: 221-241

> Johansen LH, Sommer AI (1995) Multiplication of infectious pancreatic necrosis virus (Ipnv) in head kidney and blood leukocytes isolated from Atlantic salmon, Salmo salar L. J Fish Dis 18:147-156

Johansen LH, Sommer AI (2001) Infectious pancreatic necrosis virus infection in Atlantic salmon Salmo salar postsmolts affects the outcome of secondary infections with infectious salmon anaemia virus or Vibrio salmonicida. Dis Aquat Org 47:109-117

> Lannan CN, Winthon JR, Fryer JL (1984) Fish cell lines: establishment and characterization of nine cell lines from salmonids. In Vitro 22:671-676

Lenschow D, Lai C, Frias-Staheli N, Giannakopoulos N and others (2007). IFN-stimulated gene 15 functions as a critical antiviral molecule against influenza, herpes, and Sindbis viruses. Proc Natl Acad Sci USA 104:1371-1376

Livak KJ, Schmittgen TD (2001) Analysis of relative gene expression data using real-time quantitative PCR and the 2(-Delta Delta C(T)). Methods 25:402-408

Lockhart K, Gahlawat SK, Soto-Mosquera D, Bowden TJ, Ellis AE (2004) IPNV carrier Atlantic salmon growers do not express Mx mRNA and poly I:C-induced Mx response does not cure the carrier state. Fish Shellfish Immunol 17:347-352

Lorenzen E, Olesen N, Strøm A, Evensen Ø (1995) Outbreaks of IPN in reared fry of Atlantic cod (Gadus morhua). In: Bernoth EM (ed) 7th Int EAFP Conf 'Diseases of Fish \& Shellfish', Palma de Mallorca, 10-15 September, p 38 (Abstract) 
Martin-Armas M, Sommer AI, Smedsrød B (2007) Studies on uptake and intracellular processing of infectious pancreatic necrosis virus by Atlantic cod scavenger endothelial cells. J Fish Dis 30:701-710

McBeath AJA, Snow M, Secombes CJ, Ellis AE, Collet B (2007) Expression kinetics of interferon and interferoninduced genes in Atlantic salmon (Salmo salar) following infection with infectious pancreatic necrosis virus and infectious salmon anaemia virus. Fish Shellfish Immunol 22:230-241

Melby HP, Krogsrud J, Håstein T, Stenwig H (1991) All commercial Atlantic salmon seawater farms in Norway harbour carriers of infectious pancreatic necrosis virus (IPNV). In: Fryer JL (ed) 2nd Int Symp on Viruses of Lower Vertebrates. Oregon State University, Corvallis, OR, p 211-217

Mortensen S, Evensen Ø, Rødseth O, Krogsrud J, Christie KE (1990) Infectious pancreatic necrosis virus, serotype N1, isolated from Norwegian turbot (Scophthalmus maximus), halibut (Hippoglossus hippoglossus) and scallops (Pecten maximus). Bull Eur Assoc Fish Pathol 10:42-43

Munro ES, Gahlawat SK, Acosta F, Ellis AE (2006) In infectious pancreatic necrosis virus carrier Atlantic salmon, Salmo salar L., post-smolts, almost all kidney macrophages ex vivo contain a low level of non-replicating virus. J Fish Dis 29:43-48

Novoa B, Figueras A, Puentes CF, Ledo A, Toranzo AE (1993) Characterization of a birnavirus isolated from diseased turbot cultured in Spain. Dis Aquat Org 15:163-169

> Novoa B, Barja JL, Figueras A (1995a) Entry and sequential distribution of an aquatic birnavirus in turbot (Scophthalmus maximus). Aquaculture 131:1-9

Novoa B, Rivas C, Toranzo AE, Figueras A (1995b) Pathogenicity of birnaviruses isolated from turbot (Scophthalmus maximus) - comparison with reference serotypes of IPNV. Aquaculture 130:7-14

> Okumura A, Lu G, Pitha-Rowe I, Pitha PM (2006) Innate antiviral response targets HIV-1 release by the induction of ubiquitin-like protein ISG15. Proc Natl Acad Sci USA 103:1440-1445

> Overturf K, LaPatra S (2006) Quantitative expression (Walbaum) of immunological factors in rainbow trout, Oncorhynchus mykiss (Walbaum), after infection with either Flavobacterium psychrophilum, Aeromonas salmonicida, or infectious haematopoietic necrosis virus. J Fish Dis 29: 215-224

Poisa-Beiro L, Dios S, Montes A, Aranguren R, Figueras A, Novoa B (2008) Nodavirus increases the expression of $\mathrm{Mx}$ and inflammatory cytokines in fish brain. Mol Immunol 45: 218-225

Purcell MK, Kurath G, Garver KA, Herwig RP, Winton JR (2004) Quantitative expression profiling of immune response genes in rainbow trout following infectious haematopoietic necrosis virus (IHNV) infection or DNA vaccination. Fish Shellfish Immunol 17:447-462

Reed LT, Muench H (1938) A simple method of calculating fifty percent end point. Am J Hyg 27:493-498

Roberts RJ, Pearson MD (2005) Infectious pancreatic necrosis in Atlantic salmon, Salmo salar L. J Fish Dis 28:383-390

Editorial responsibility: Mark Crane, Geelong, Victoria, Australia
Robertsen B (2006) The interferon system of teleost fish. Fish Shellfish Immunol 20:172-191

Rothenfusser S, Goutagny N, DiPerna G, Gong M and others (2005) The RNA helicase LGP2 inhibits TLR-independent sensing of viral replication by retinoic acid-inducible gene-I. J Immunol 175:5260-5268

Saint-Jean SR, Borrego JJ, Perez-Prieto SI (2003) Infectious pancreatic necrosis virus: biology, pathogenesis, and diagnostic methods. Adv Virus Res 62:113-165

Santi N, Vakharia VN, Evensen O (2004) Identification of putative motifs involved in the virulence of infectious pancreatic necrosis virus. Virology 322:31-40

Seppola M, Stenvik J, Steiro K, Solstad T, Robertsen B, Jensen I (2007) Sequence and expression analysis of an interferon stimulated gene (ISG15) from Atlantic cod (Gadus morhua L.). Dev Comp Immunol 31:156-171

Seppola M, Larsen AN, Steiro K, Robertsen B, Jensen I (2008) Characterisation and expression analysis of the interleukin genes, IL-1beta, IL-8 and IL-10, in Atlantic cod (Gadus morhua L.). Mol Immunol 45:887-897

Seternes T, Dalmo RA, Hoffman J, Bogwald J, Zykova S, Smedsrod B (2001) Scavenger-receptor-mediated endocytosis of lipopolysaccharide in Atlantic cod (Gadus morhua L.). J Exp Biol 204:4055-4064

Seternes T, Sorensen K, Smedsrod B (2002) Scavenger endothelial cells of vertebrates: a nonperipheral leukocyte system for high-capacity elimination of waste macromolecules. Proc Natl Acad Sci USA 99:7594-7597

Skall HF, Mellergaard S, Olesen NK (2000) Isolation of Birnavirus serogroup B in wild and aquacultured fish species. Bull Eur Assoc Fish Pathol 20:229-236

> Sommer AI, Amundsen Strand M, Rasmussen E, Mennen S (2004) Susceptibility of spotted wolffish Anarhichas minor to experimental infection with nodavirus and infectious pancreatic necrosis virus. Dis Aquat Org 59:101-108

> Tafalla C, Coll J, Secombes CJ (2005) Expression of genes related to the early immune response in rainbow trout (Oncorhynchus mykiss) after viral haemorrhagic septicemia virus (VHSV) infection. Dev Comp Immunol 29: $615-626$

Tafalla C, Saint-Jean SR, Perez-Prieto S (2006) Immunological consequences of the coinfection of brown trout (Salmo trutta) with infectious hematopoietic necrosis virus (IHNV) and infectious pancreatic necrosis virus (IPNV). Aquaculture 256:15-22

Taksdal T, Ramstad A, Stangeland K, Dannevig BH (1998) Induction of infectious pancreatic necrosis (IPN) in Covertly infected Atlantic salmon, Salmo salar L., post smolts by stress exposure, by injection of IPN virus (IPNV) and by cohabitation. J Fish Dis 21:193-204

Wedemeyer GA (1997) Effects of rearing conditions on the health and physiological quality of fish in intensive culture. In: Iwama GK, Pickering AD, Sumpter JP, Schreck CB (eds) Fish stress and health in aquaculture. Cambridge University Press, Cambridge, p 35-71

Yoneyama M, Kikuchi M, Matsumoto K, Imaizumi T (2005) Shared and unique functions of the DExD/H-box helicases RIG-I, MDA5, and LGP2 in antiviral innate immunity. J Immunol 175:2851-2858

Submitted: January 18, 2008; Accepted: April 7, 2009 Proofs received from author(s): May 29, 2009 